\title{
Genetic structure of natural stands of Fagus sy/vatica L. (beech)
}

\author{
D. MERZEAU*, B. COMPS, B. THIÉBAUT†, J. CUGUEN $\ddagger$ \& J. LETOUZEY \\ Université de Bordeaux I, Département de Biologie des Végétaux ligneux, Avenue des Facultés 33405 Talence \\ †Université de Montpellier II, Institut de Botanique, 163 Rue A. Broussonet, 34000 Montpellier and CNRS Centre Louis \\ Emberger, BP 505134033 Montpellier and $\ddagger$ Université de Lille 1, URA CNRS 1185, Laboratoire de Génétique et \\ Evolution des Populations Végétales, Bat. SN2 and Institut Agricole et Alimentaire de Lille 59655 Villeneuve d'Ascq \\ Cédex, France
}

\begin{abstract}
The spatial genetic structures of three French natural beech stands were analysed using polymorphic enzyme loci. Two methods were used: $F$-statistics and spatial autocorrelation statistics. Within these stands where self-fertilization rate is 0 , a low heterozygote deficit was observed which may be due to a moderate level of mating between relatives. However, no increase of this deficit was observed from one generation to the next. The spatial genetic structuring was low. Within one open stand composed of several patches, founder events are invoked to explain a significant autocorrelation. Within the two other stands, both dense, results are similar to those produced by simulations of an isolation by distance model. The genetic structure seems not to be stable in space and time which may be due to (i) a limited number of generations; (ii) an effective gene flow less limited than hypothesized; and (iii) fertility differences or phenological incompatibilities between individuals.
\end{abstract}

Keywords: beech stands, Fagus sylvatica L., genetic structures, spatial autocorrelation.

\section{Introduction}

In common with other species of forest trees (see review in Müller-Starck et al., 1992; Hamrick et al., 1992) a high genetic diversity has been found in beech, Fagus sylvatica L. (Cuguen et al., 1985; Comps et al., 1990, 1991). This variation is distributed within and among populations, the within population component being generally higher.

In temperate regions, most tree species, including beech, are monoecious, wind-pollinated, allogamous and self-incompatible. However, forests cannot be considered as genetically homogeneous panmictic populations. Indeed, their genetic diversity is often structured in space and time and genetic differentiation can occur over relatively short distances (Sakai \& Park, 1971; Mitton et al., 1977, 1981; Linhart et al., 1981; Knowles, 1984; Shea, 1985; Gullberg et al., 1985). Such genetic differentiation may be the result of either diversifying selection in an heterogeneous environment or limited gene flow. The latter cause of differentiation can be considered using an isolation by distance model (Wright, 1943, 1946) in which for two individuals the probability of mating is negatively correlated with their geographical separation and reproduction is likely to occur between related individuals. This mode of repro-

*Correspondence. duction has been proposed for beech populations (Gregorius et al., 1986; Cuguen et al., 1988; Comps et al., 1990, 1991), implying that genetic diversity of beech populations is organized in space and time.

A number of methods has been used for the detection of spatial heterogeneity of genetic variation within populations. In a population clearly fragmented into patches or in a continuous population where physiognomic units are visible, the distribution of genetic variation can be studied among existing patches or groups (Linhart et al., 1981). Within continuous populations, numerous methods have been employed to study the spatial patterns of variation, ranging from visual inspection of mapped variants (Tigerstedt, 1973; Van Damme, 1986), linear transects (Hamrick et al., 1979; Knowles, 1984; Knowles \& Grant, 1985; Shea, 1985; Learn \& Schaal, 1987) and comparison of quadrat subsamples (Schaal, 1975). Such methods of analysing population substructure are limited by the need to choose an arbitrary quadrat size and the within quadrat substructure may be ignored (Epperson \& Clegg, 1986).

Spatial autocorrelation analysis (Sokal \& Oden, 1978) can reveal patterns of genetic variation at a wide range of scale. In some conditions it can permit the inference of evolutionary causes of spatial patterns (Sokal \& Wartenberg, 1983; Sokal et al., 1989; Epperson, 1990; Sokal \& Jacquez, 1991; but see Slatkin \& 
Arter, 1991; Sokal \& Oden, 1991 for a reply). The statistical analysis requires no a priori assumptions regarding the scale of spatial patterning of genotypes. Indeed, these statistics measure the dependence of a character at each location on the character values at other locations. This procedure has only recently been applied to the study of genetic variation within plant populations (see Heywood, 1991 for a review). Among tree species, investigations of spatial autocorrelation in lodgepole pine (Epperson \& Allard, 1989) and black spruce (Knowles, 1991) have indicated that single locus genotypes are distributed in a nearly random fashion whereas a significant small-scale genetic structure was detected in sugar maple (Perry \& Knowles, 1990) and in a sympatric stand of Pinus banksiana and Pinus contorta (Wagner et al., 1991).

In the present study, we have applied autocorrelation analysis to allozyme data of three naturally occurring beech populations varying in density of individuals (Merzeau, 1991). Pollen dispersal is expected to be greater in open stands than in dense forests (Rudin et al., 1974; Coles \& Fowler, 1976; Cheliak et al., 1984; Thiébaut et al., 1990). In each population two successive generations have been sampled to check for temporal changes.

\section{Materials and methods}

\section{Studied populations}

Three mature, naturally regenerated beech stands were selected in the Pyrenees mountains and two generations were clearly identified in each stand. Stand 1 was located in the Issaux forest $\left(43^{\circ} 00 \mathrm{~N}-0^{\circ} 43 \mathrm{~W}\right.$, elevation $1000 \mathrm{~m}$ ) while stands 2 and 3 were located in the Lazerque forest $\left(42^{\circ} 90 \mathrm{~N}-0^{\circ} 42 \mathrm{~W}\right.$, elevations $1400 \mathrm{~m}$ and $1600 \mathrm{~m}$, respectively). Each site is occupied by a monospecific beech forest and the two forests are separated by approximately $10 \mathrm{~km}$.

In stand 1 (Issaux), the population of adult trees was subdivided into four groups on the basis of topographical differences. Young individuals were located in a clearing which was subdivided into two groups along a slope. Densities of trees are 160 trees/ha on average for the adults and from 0.16 individuals $/ \mathrm{m}^{2}$ to $23 / \mathrm{m}^{2}$ for the juveniles. A total of 164 adult trees and 154 juveniles was sampled and their positions were mapped. Stand 2 (Lazerque dense forest) is located within a continuous and densely forested area where adult density is about 375 individuals/ha. Paired samples were collected, 136 contiguous trees being sampled and mapped. At each sampling site, the closest juvenile to the adult tree was also collected. Stand 3 (Lazerque open forest) is located near the upper altitudinal limit for beech in the region. The forest is discontinuous and subdivided into several groups. Ten groups were sampled and mapped, both adults and juveniles being sampled.

\section{Biochemical study}

Bud tissue was collected from each individual for electrophoresis. Eight polymorphic enzyme loci were resolved (GOT1, IDH1, 6PGD1, PG11, PX1, PX2, $M D H 1$ and $S O D 1)$. Electrophoretic conditions were as previously described (Thiébaut $e t$ al., 1982; Merzeau et al., 1989).

\section{Genetical analyses}

$F$-statistics (Wright, 1951, 1965) were used to analyse the subpopulation genetic structure in Issaux and Lazerque open forests. The corrected method of Weir \& Cockerham (1984) was used for calculation. In Lazerque dense stand, which is not subdivided into groups, we estimated Wright's fixation index (Kirby, 1975; Nei, 1977, 1978).

\section{Spatial autocorrelation analyses}

Tests for non-random distribution of genotypes were performed for each locus using spatial autocorrelation statistics (Sokal \& Oden, 1978; Cliff \& Ord, 1981). Two methods were used in which genotypes were considered as either nominal data or as interval data. In the case of nominal data, the observed number of 'likepairs' of genotypes, in which both trees of a pair shared the same genotype, were enumerated. 'Unlike-pairs' were also enumerated. These numbers were compared with expected numbers under the null hypothesis of a random distribution of genotypes. Autocorrelation statistics were computed as standard normal deviates (SND). In the case of interval data, the genetic data were coded such that single trees received allele frequency values of $0,0.5$ or 1 for each allele at every locus. Alleles with too low a frequency were excluded and only one allele was considered at diallelic loci. Moran's I was estimated (Moran, 1950).

Two criteria for considering any pair of individuals were used. The first is Gabriel-connectedness (Gabriel \& Sokal, 1969). We made a Gabriel-connected graph for each stand. This algorithm pairs two individuals A and $\mathrm{B}$ if no other individual lies on or within the circle whose diameter is the line $\mathrm{AB}$. This connection model is used to test for the lack of autocorrelation between nearest neighbours.

Examination of spatial genetic structure, i.e. behaviour of the autocorrelation statistics as inter- 
individual distance increases, was made through the construction of correlograms. Euclidian distances between the two trees of all possible pairs were calculated, permitting assignment of all pairs to distance classes. Distance classes were defined using equal intervals. For each stand, distance interval corresponds to the mean distance between individuals connected according to Gabriel algorithm: thus the first distance class includes most nearest neighbours.

\section{Results}

\section{Temporal variation of genetic structure}

In each of the three stands there is no significant difference in allelic frequencies between generations except for the $P X 2$ and SOD1 loci in Issaux (Table 1). The sign of the fixation index and of $F_{n}$ varies from one locus to the other within each generation (Table 2). For the adults, a significant deficit was found in Issaux $(S O D 1)$ and Lazerque dense $(M D H 1)$ whereas a significant excess was observed in Lazerque open $(P X 1)$. For the juveniles, a significant excess of heterozygotes was found for two loci out of five in Issaux ( $P X 2$ and $M D H 1)$. There is a trend for an excess of heterozygotes in juveniles compared with adults for almost all loci: in nine cases out of 12, and especially in Issaux forest, $F$ or $F_{i t}$ were lower in the juveniles than in the adults. Within each of the three populations, the juvenile multilocus value tends to be lower than that of the adults.

In Issaux and Lazerque open, unilocus $F_{s t}$ values were low, except for the locus GOTI in juveniles from Issaux. Multilocus $F_{s t}$ were similar for the two generations whatever the population. $F_{s t}$ differed significantly from zero only for the juveniles from Issaux, indicating a slight differentiation among groups in this generation.

Five unilocus $F_{i s}$ values out of 12 were significantly different from zero and reveal (i) a heterozygote deficit in adults from Issaux (SOD1), and (ii) a heterozygote excess in juveniles from Issaux $(P X 2$ and $M D H I)$ and in both adults and juveniles from the Lazerque open forest $(P X 1)$. Multilocus $F_{\text {is }}$ was significantly negative only for the juveniles in Issaux. Multilocus $F_{i s}$ was higher for adults compared with juveniles in Issaux and Lazerque open forest.

\section{Spatial genetic structure}

Proximal distances. Particular attention has been focused on the short distances corresponding to those between nearest neighbours because most forms of population structure are likely to produce greater autocorrelation at short distance than at longer distance.
With the Gabriel-connectedness method, the autocorrelation analysis yielded no significant results within each stand for ordinal data. For nominal data, five values among a total of 35 normal standard deviates were significantly different from zero for the adults from Issaux (MDH1 and GOT1 loci, Table 3). For $M D H 1$ locus, there occurred both an excess of joins between homozygotes 1 and a deficit of joins between homozygotes 1 and heterozygotes, corresponding to a grouping of homozygotes into homogeneous patches. In contrast, for locus GOTI, there is an alternate spatial distribution of these two genotypes. In juveniles from Issaux the most interesting result was obtained for the GOT1 locus: an excess of neighbour homozygotes, respectively 1 and 3 , and a deficit of connections between these two genotypes.

Within the Lazerque dense forest, adults present an excess of neighbour homozygotes 1 at $P X I$ and GOTI loci (Table 3). At the $P X 2$ locus there is (i) an excess of connections between heterozygotes $2-2$ in adults, which disappears when grouping rare genotypes, and (ii) a grouping of neighbour homozygotes 1 and a deficit of connections $1-3$ in juveniles. At the GOTI locus there is an alternate distribution of the two homozygotes 1 and 3 in juveniles. In Lazerque open forest there is only one significant value (connections between heterozygotes 2-2 at PX2 locus, in adults).

Correlograms. Within the three stands studied, the examination of allelic and genotypic correlograms revealed in some cases the existence of spatial structuring. Nevertheless, the number of significant values was low. In juveniles from the Lazerque dense forest the allelic correlograms for $M D H 1$ locus indicates that individuals possessing similar alleles were more often proximal than expected purely by chance (Fig. 1). In juveniles from Issaux, the allelic correlogram for the GOTI locus was characterized by a large number of significant values (Fig. 2). There is a quite monotonous decrease of Moran's $I$ statistics with increasing distance. These results are confirmed by the genotypic correlograms (Fig. 2) where significant excesses of likepairs of genotypes are observed in the short distance classes. In adults from the Lazerque open forest, Moran's $I$ was significantly positive for $P X 2-40$ and $P X 2-46$ alleles at distances corresponding to within patch joins and negative at distances corresponding to among neighbouring patch joins (Fig. 3).

In every other case, correlograms do not differ from a random distribution.

\section{Discussion}

The prevailing idea concerning the mating system of forest trees is that, within a population, an individual is 


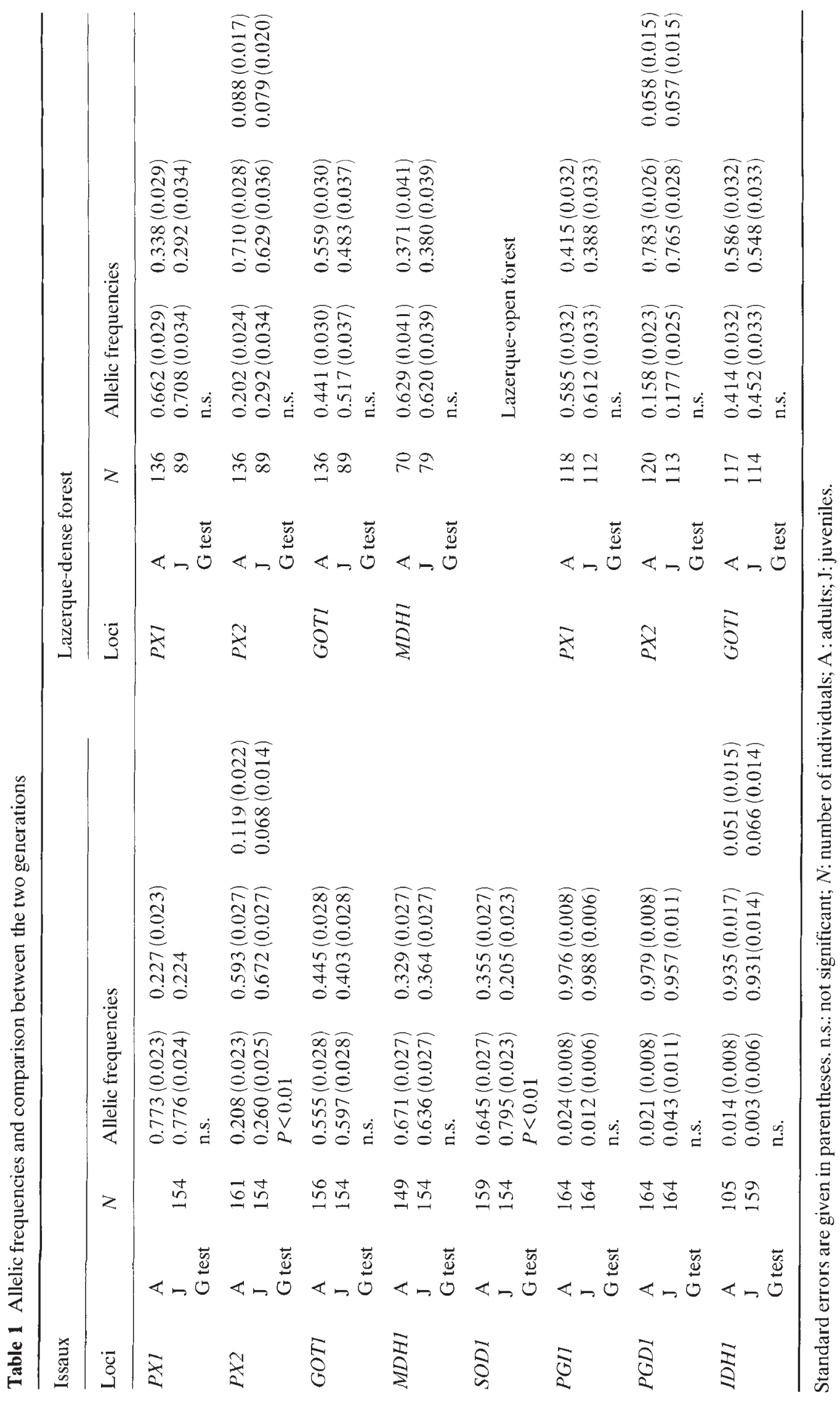


Table 2 Within generation genetic structures

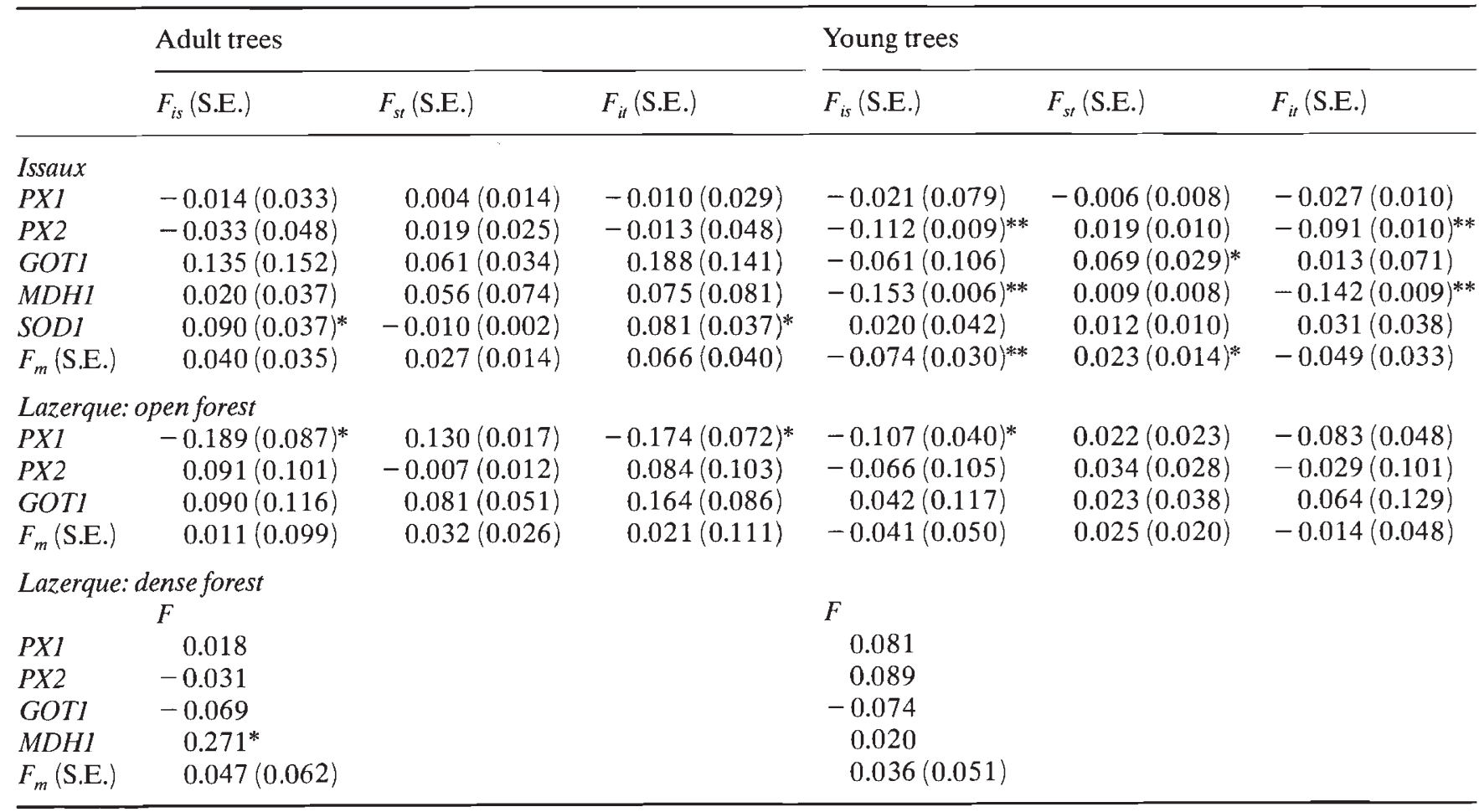

$F$ statistics (Weir \& Cockerham, 1984) (Issaux and Lazerque open forest) and fixation index $F$ (Lazerque, dense forest).

$F_{m}$ : mean values; S.E.: standard errors.

$* * 0.001<P<0.01 ; * 0.01<P<0.05$.

likely to be preferentially pollinated by its close neighbours. The major consequences of this for neutral genes are an increase of relatedness and inbreeding and within population differentiation. The effects are amplified from one generation to the next with a further reduction in gene flow being caused by forest closing.

\section{Temporal variation in genetic structure}

Multilocus $F_{s t}$ values show a similar degree of differentiation both in the stands, described here over short distances, and in European beechwoods as a whole (Cuguen, 1986). They are similar to those for other anemophilous tree species (Knowles, 1984; Mitton et al., 1981), whatever the population physiognomy and the generation.

If the differentiation observed over short distances is caused by mating between related individuals, inbreeding must be more important than it is in the case of only self-fertilization. In the stands studied, self-fertilization was found to be equal to 0 (D. Merzeau et al., unpublished data) and the low heterozygote deficit observed suggests a rather moderate level of inbred mating.
Moreover, such matings would induce an increasing heterozygote deficit from one generation to the next. Such an increase was not observed in the beech stands studied here. The absence of heterozygote deficit in juveniles could be due to their age (more than 10 years old) or, in the Lazerque open forest, by unlimited gene flow. An heterozygote excess can be explained by differences in allelic frequencies between ovule and pollen pools (Ziehe, 1983; Cheliak, 1985; Muona \& Szmidt, 1985). Such differences would have occurred in Issaux forest where the regeneration occurs in forest openings (gap-generation) (Cuguen, 1986; Nakashizuka, 1984), a feature which would have induced both an increase in pollen flow and a reduction in the number of mother-trees (and therefore of the ovule pool) producing groups of allelic frequencies which are not generally representative of the population.

\section{Spatial genetic structure}

The small number of significant autocorrelation values observed reveals a weak spatial genetic structuring. In the cases of these significant values, two kinds of spatial 
Table 3 Genotypic autocorrelation standard normal deviate values $Z_{i j}$

\begin{tabular}{|c|c|c|c|c|c|c|c|}
\hline & & $1-1$ & $2-2$ & $3-3$ & $1-2$ & $1-3$ & $2-3$ \\
\hline \multicolumn{8}{|l|}{ Issaux } \\
\hline & $P X I$ & 1.86 & 0.24 & 0.50 & -1.35 & 0.26 & -0.89 \\
\hline \multirow{4}{*}{ Adults } & $P X 2$ & 0.80 & -0.33 & 1.16 & $2.02 *$ & -1.79 & -1.22 \\
\hline & GOTI & $-2.43^{*}$ & -0.36 & 1.66 & $2.95^{*}$ & -1.10 & -1.19 \\
\hline & MDHI & $3.08^{* *}$ & 0.33 & 1.53 & $-2.13^{*}$ & -1.05 & -0.16 \\
\hline & $S O D 1$ & -0.26 & -0.26 & 0.41 & 0.51 & -1.43 & 1.01 \\
\hline \multirow{5}{*}{ Juveniles } & $P X 1$ & 0.74 & 1.10 & 0.92 & -1.06 & -1.02 & 0.57 \\
\hline & $P X 2$ & $2.50^{*}$ & 0.25 & 0.83 & $2.66^{*}$ & $2.07^{*}$ & -1.24 \\
\hline & GOTI & $3.01^{* *}$ & -0.84 & $3.12^{* *}$ & 0.45 & $-2.25^{*}$ & -1.61 \\
\hline & $M D H I$ & -0.64 & 0.21 & 0.06 & -0.2 & -0.57 & 0.92 \\
\hline & SOD1 & -0.46 & -0.89 & 0.92 & 0.24 & -0.95 & 1.84 \\
\hline \multicolumn{8}{|c|}{ Lazerque: dense forest } \\
\hline \multirow{4}{*}{ Adults } & $P X 1$ & $3.94 * *$ & 0.27 & 1.40 & -1.78 & -1.89 & -0.34 \\
\hline & $P X 2$ & -0.26 & $2.04 *$ & -0.57 & 0.67 & 0.56 & -0.72 \\
\hline & GOTI & $2.88^{* *}$ & -0.75 & 1.35 & 0.89 & -1.35 & -1.05 \\
\hline & $M D H I$ & -0.02 & 1.17 & 1.04 & -0.24 & -0.41 & -0.76 \\
\hline \multirow{4}{*}{ Juveniles } & $P X 1$ & 1.13 & 1.09 & -0.79 & -1.18 & -0.75 & 0.33 \\
\hline & $P X 2$ & $4.83^{* * * * * *}$ & 1.66 & 1.49 & -0.03 & $-2.60^{\text {*** }}$ & -1.41 \\
\hline & GOT1 & -0.39 & 0.55 & -0.29 & -0.63 & $2.59 * *$ & -1.44 \\
\hline & $M D H 1$ & 1.85 & -1.57 & 0.39 & -0.15 & -1.36 & 1.05 \\
\hline \multicolumn{8}{|c|}{ Lazerque: open forest } \\
\hline \multirow{3}{*}{ Adults } & $P X 1$ & 1.66 & 0.54 & -1.08 & -0.54 & -0.94 & 0.01 \\
\hline & $P X 2$ & & $3.26^{* *}$ & -0.16 & 1.82 & -0.29 & -1.20 \\
\hline & GOT1 & 1.57 & -0.07 & 1.57 & 0.17 & -1.02 & -0.09 \\
\hline \multirow{3}{*}{ Juveniles } & $P X 1$ & 0.44 & 0.48 & -1.62 & -1.02 & -1.03 & 1.90 \\
\hline & $P X 2$ & & 0.82 & 0.78 & & & -0.08 \\
\hline & GOTI & 1.41 & 0.26 & 0.11 & -1.48 & -1.18 & 1.77 \\
\hline
\end{tabular}

1, 3: homozygotes; 2: heterozygote; for $P X 2$ locus, 2 = heterozygote $40-46$, all other joins are not reported on the table (no significant values).

** $0.001<P<0.01 ; * 0.01<P<0.05$.

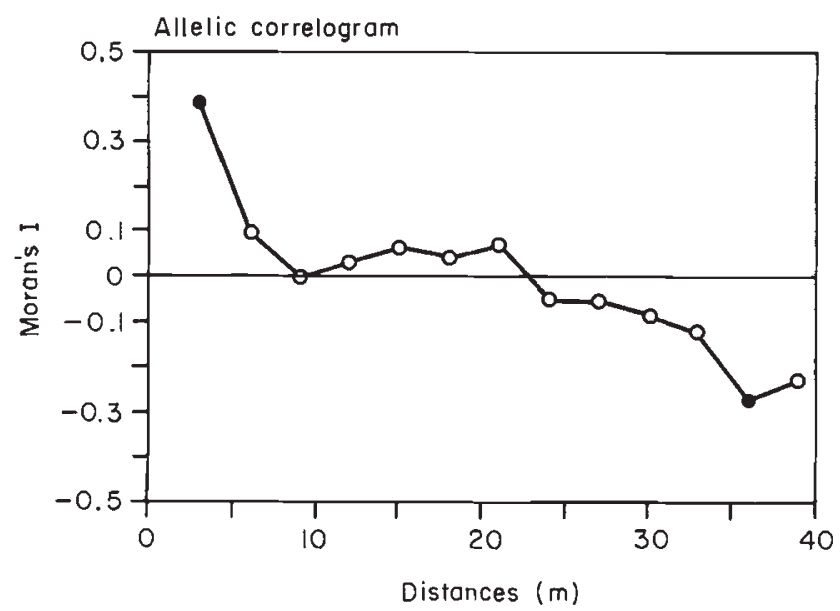

Fig. 1 Lazerque, dense forest, natural regeneration: spatial autocorrelation at $M D H I$ locus. structuring can be described. With Lazerque open forest, significant autocorrelation was found, positive within patches and negative between patches. A selection hypothesis is not very likely on this scale. On the contrary, this kind of spatial structuring is likely to have originated from founder events (Sokal \& Oden, 1978). Within Issaux and Lazerque dense stands, the significant correlograms are similar to those produced by simulation of an isolation by distance model (Sokal \& Wartenberg, 1983; Sokal \& Jacquez, 1991). However, in most cases we observed no significant departures from a random distribution of genotypes. A number of spatial autocorrelation analyses in other studies have failed to detect any significant spatial structuring in plant populations (Waser 1987; Dewey \& Heywood, 1988; Epperson \& Allard, 1989; Knowles, 1991). 

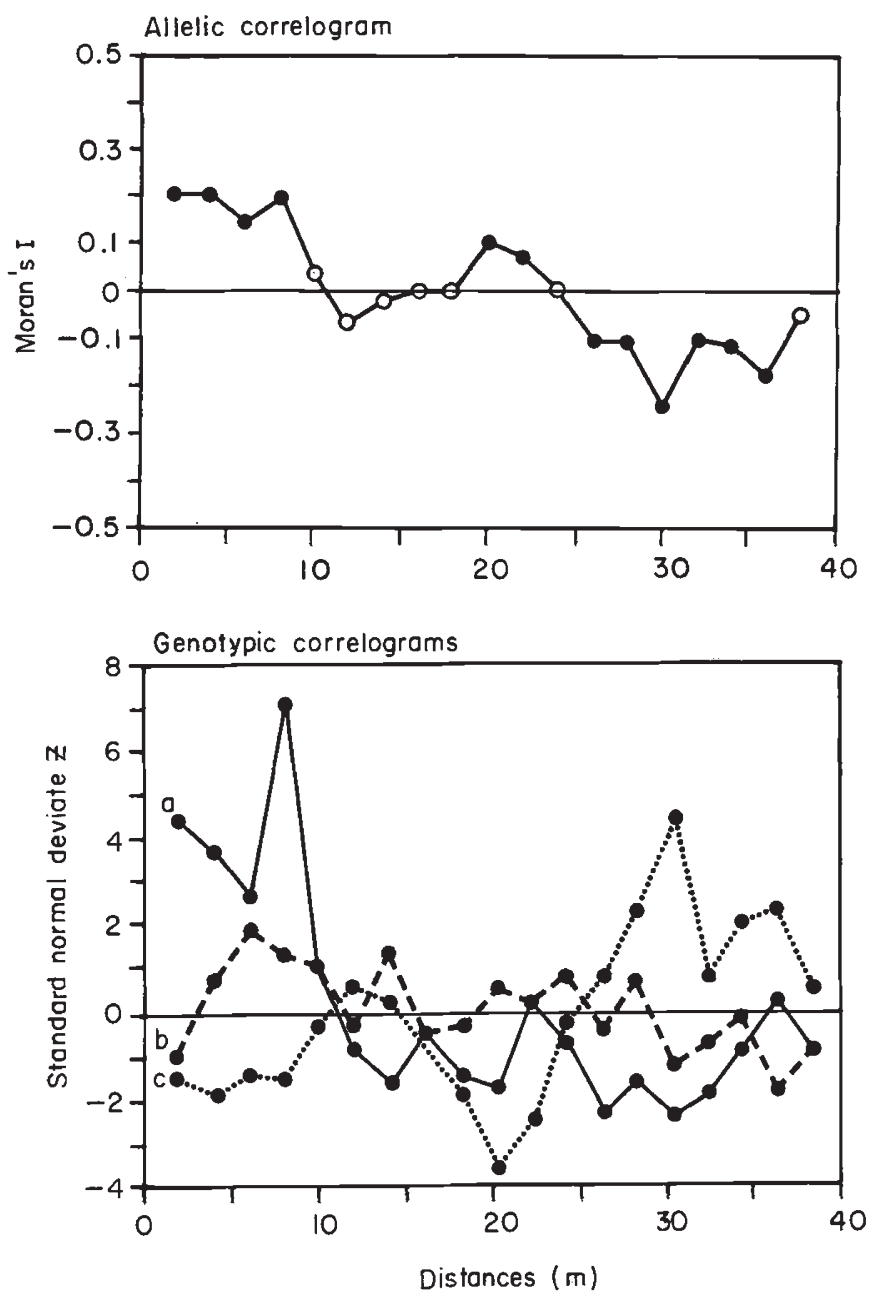

Fig. 2 Issaux, forest clearing, natural regeneration: spatial autocorrelation at $G O T 1$ locus. (a) Joins between homozygotes GOT1-105(3-3), (b) joins between homozygotes $G O T 1-100(1-1)$, (c) joins between the two homozygotes $(1-3)$.

In our study, for a given generation within a population, autocorrelation values differ from one locus to another whereas at equilibrium in an isolation by distance model, without selection, one would expect the same values at different loci. The observed heterogeneity among loci may indicate a lack of equilibrium caused by the relative juvenility of the forests being studied. Thus the observed distribution may be influenced by the random genetic composition of the earliest founders.

In conclusion, the genetic structure of the three beech populations seems not to be stable, either in space or time, a fact which generates at least three alternative hypotheses. First, there may have been only a limited number of generations since the founda-
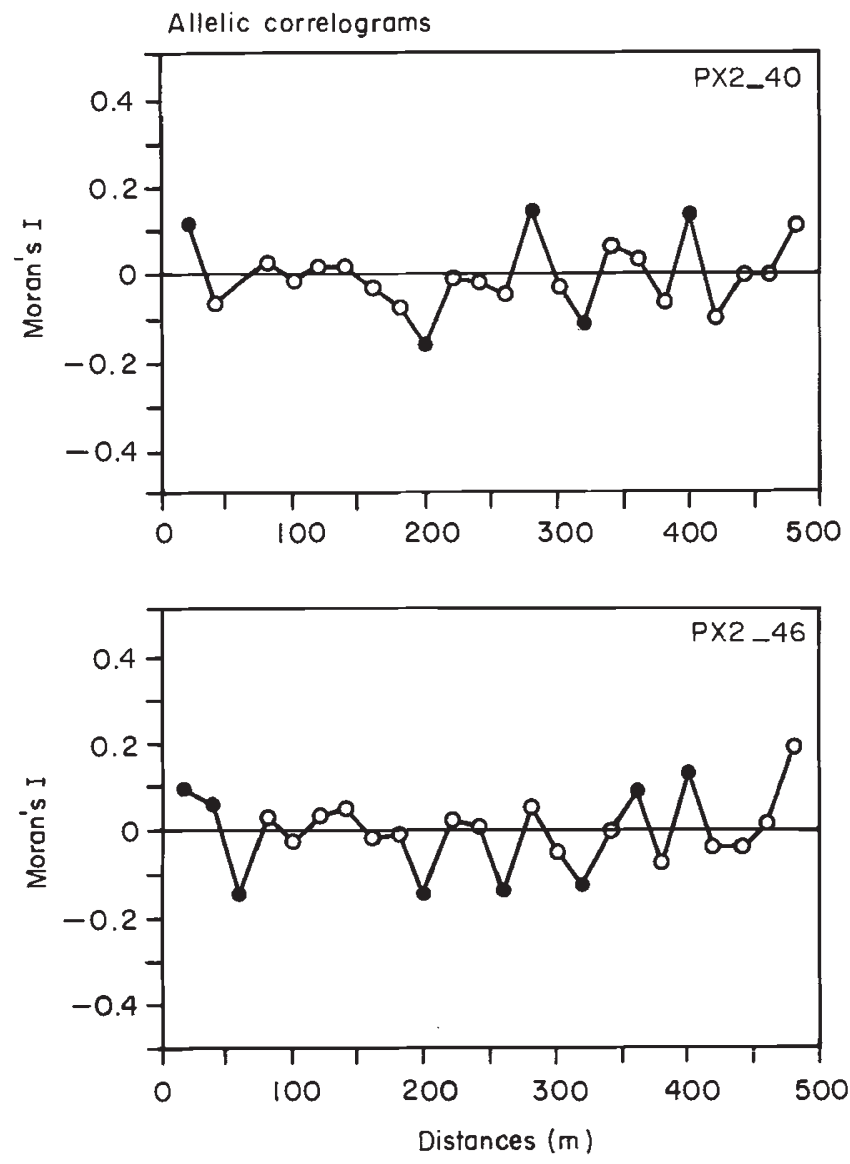

Fig. 3 Lazerque, open forest: spatial autocorrelation for adult tree gene frequencies $(P X 2)$.

tion of the populations. Indeed, optimal sexual maturity is only achieved after 50 years leading to a long generation time. On the other hand, a beechwood experiences cyclic phenomena of colonization and extinction due to human or natural perturbations. Secondly, effective gene flow could be less limited than previously suggested (Tigersted et al., 1982; Yazdani et al., 1985; Yacine, 1987). The inability to detect spatial structure could be explained by the possible leapfrog nature of gene flow (Waser, 1987), i.e. the effective pollen dispersal distance could be larger than the immediate distance between close neighbours. Thirdly, the probability of mating between two individuals may not only be related to their geographical distance. Other important factors may be involved, such as fertility differences between individuals (Oswald, 1984) and phenological incompatibilities (equivalent to a temporal isolation between mates) (Comps et al., 1987). For efficient reproduction, a tree has to be pollinated by a synchronously flowering fertile individual having a high resource allocation towards 
male function, all characters which are subject to wide inter-annual variation.

\section{Acknowledgements}

The authors are very grateful to R. M. Guilbaud and $\mathrm{S}$. Vodichon for their technical assistance.

\section{References}

CHELIAK, w. M. 1985. Mating system dynamics in a Scots pine seed orchard. In: Gregorius, H. R. (ed.) Population Genetics in Forestry, pp. 107-119. Springer Verlag, Berlin. CHELIAK, W. M., MORGAN, K., DANCIK, B. P. AND YEH, F. C. 1984. Segregation of allozymes in megagametophytes of viable seed from a natural population of Jack pine, Pinus banksiana Lamb. Theor. Appl. Genet., 69, 145-151.

ClifF, A. A. AND ORD, J. K. 1981. Spatial Processes: Models and Applications. Pion ed., London.

COLES, J. F. AND FOWLER, D. P. 1976 . Inbreeding in neighbouring trees in two white spruce populations. Silvae Genetica, 25, 29-34.

COMPS, B., Letouzey, J. AND SAvole, J. M. 1987. Phénologie du couvert arborescent dans une chênaie-hêtraie d'Aquitaine. Ann. Sci. For., 44, 153-170.

COMPS, B., THIEBAUT, B., PAUle, L., MERZEAU, D. AND LETOUZEY, J. 1990. Allozymic variability in beechwoods (Fagus sylvatica L.) over central Europe: spatial differentiation among and within populations. Heredity, 65, 407-417.

COMPS, B., THIEBAUT, B., SUGAR, I., TRINAJSTIC, I. AND PLAZIBAT, M. 1991. Genetic variation of the Croatian beech stands (Fagus sylvatica L.): spatial differentiation in connection with the environment. Ann. Sci. For, 48, 15-28.

Cuguen, J. 1986. Différenciation génétique inter-et intrapopulation d'un arbre forestier anémophile: le cas du Hêtre (Fagus sylvatica L.). Thèse Doct. Université, Université des Sciences et Techniques du Languedoc, Montpellier.

Cuguen, J., MERzeau, D. AND thiebaut, B. 1988. Genetic structure of the European beech stands (Fagus sylvatica L.): F-statistics and importance of mating system characteristics in their evolution. Heredity, 60, 91-100.

CUGUen, J., THIEBAUt, B., N'TSIBA, F. AND BARRIERE, G. 1985. Enzymatic variability of beechstands (Fagus sylvatica L.) on three scales in Europe: evolutionary mechanisms. In: Jacquart, P., Heim, G. and Antonovics, J. (eds) Genetic Differentiation in Plants, pp. 17-39. NATO ASI Series G5.

DEWEY, S. E. AND HEYWOOD, J. S. 1988. Spatial genetic structure in a population of Psychotria nervosa. I. Distribution of genotypes. Evolution, 42, 834-838.

EPPERSON, B. K. 1990. Spatial autocorrelation of genotypes under directional selection. Genetics, 124, 757-771.

EPPERSON, B. K. AND ALLARD, R. w. 1989. Spatial autocorrelation analysis of the distribution of genotypes within populations of lodgepole pine. Genetics, 121, 369-378.

EPPERSON, B. K. AND CLEGG, M. T. 1986. Spatial autocorrelation analysis of flower color polymorphisms within substructured populations of morning glory (Ipomea purpurea). Am. Nat., 128, 840-858.
GABRIEL, K. R. AND SOKAL, R. R. 1969. A new statistical approach to geographic variation analysis. Systematic Zoology, 18, 259-270.

GREGORIUS, H. R., KRAUHAUSEN, J. AND MÜLLER-STARCK, G. 1986. Spatial and temporal genetic differentiation among the seed in a stand of Fagus sylvatica. Heredity, 57, 255-262.

GUllBERG, U., YAZDAN1, R., RUDIN, D. AND RYMAN, N. 1985. Allozyme variation in Scot's Pine (Pinus sylvestris L.) in Sweden. Silvae Genetica, 34, 193-201.

HAMRICK, J. L., GODT, M. J. W. AND SHERMAN-BROYLES, S. L. 1992. Factors influencing levels of genetic diversity in woody plant species. New Forests, 6, 95-124.

HAMRICK, J. L., MITTON, J. B. AND LINHART, Y. B. 1981. Levels of genetic variation in trees: influence of life history characteristics. In: Conkle, M. T. (ed.) Proceedings of a Symposium on Isozymes of North American forest trees and forest insects, pp. 35-47. Berkeley, California.

HEYWOOD, J. S. 1991. Spatial analysis of genetic variation in plant populations. Ann. Rev. Ecol. Syst., 22, 335-355.

KIRBY, G. C. 1975. Heterozygote frequencies in small subpopulations. Theor. Pop. Biol., 8, 31-48.

KNOWLES, P. 1984. Genetic variability among and within closely spaced populations of lodgepole pine. Can. J. Genet. Cytol., 26, 177-184.

KNOWLES, P. 1991. Spatial genetic structure within two natural stands of black spruce [Picea mariana (Mill.) B. S. P.]. Silvae Genetica, 40, 13-19.

KNOWLES, P. AND GRANT, M. C. 1985. Genetic variation of lodgepole pine over time and microgeographical space. Can. J. Bot., 63, 722-784.

LEARN, G. H. AND SCHAAL, B. A, 1987. Population subdivision for ribosomal DNA repeats variants in Clematis fremontii. Evolution, 41, 433-438.

LINHART, Y. B., MITTON, I. B., STURGEON, K. B. AND DAVIS, M. L. 1981. Genetic variation in space and time in a population of Ponderosa pine. Heredity, 46, 407-426.

MERZEAU, D. 1991. Estimation des paramètres du mode de reproduction et des structures génétiques du Hêtre (Fagus sylvatica L.). Thèse Doct. Université, Université de Bordeaux 1 .

MERZEAU, D., DI GIUSTO, F., COMPS, B., THIEBAUT, B., LETOUZEY, J. AND CUGUEN, J. 1989. Genetic control of isozyme systems and heterogeneity of pollen contribution in beech (Fagus sylvatica L.). Silvae Genetica, 38, 195-201.

MITTON, J. B., LINHART, Y. B., DAVIS, M. L. AND STURGEON, K. B. 1981. Estimation of outcrossing in Ponderosa pine, Pinus ponderosa Laws, from pattern of segregation of protein polymorphisms and from frequencies of albino seedlings. Silvae Genetica, 30, 117-121.

MITTON, J. B., LINHART, Y. B., HAMRICK, J. B. AND BECKMANN, J. S. 1977. Observations on the genetic structure and mating system of ponderosa pine in the Colorado front range. Theor. Appl. Genet., 51, 5-13.

MORAN, P. A. P. 1950. Notes on continuous stochastic phenomena. Biometrika, 37, 17-23.

MÜllER-STARCK, G., BARADAT, Ph., AND BERGMANN, F. 1992. Genetic variation within European tree species. New Forests, 6, 23-47. 
MUONA, o. AND SZMIDT, A. Z. 1985. A multilocus study of natural populations of Pinus sylvestris. In: Gregorius, H. R. (ed.) Population Genetics in Forestry, pp. 226-240. Springer Verlag, Berlin.

NAKASHISUKA, T. 1984. Regeneration process of climax beech (Fagus crenata Blume) forests. IV. Gap formation. Jap. J. Ecol., 34, 75-85.

NEI, M. 1977. F-statistics and analysis of gene diversity in subdivided populations. Ann. Hum. Genet. Lond., 41, 225-233.

NEI, M. 1978. Estimation of average heterozygosity and genetic distance from a small number of individuals. Genetics, 89, 583-590.

oswald, H. 1984. Floraison, pollinisation et fructification chez le Hêtre (Fagus sylvatica L.). In: Pesson, P. et Louveaux, J. (eds) Pollinisation et Productions Végétales, pp. 243-258. Masson, Paris.

PERRY, D. J. AND KNOWLES, P. 1990. Spatial genetic structure within three sugar maple (Acer saccharum Marsh.) stands. Heredity, 66, 137-142.

RUDIN, D., ERIKSSON, G., EKBERG, I. AND RASMUSSON, M. 1974. Studies of allele frequencies and inbreeding in Scots pine populations by the aid of isozyme technique. Silvae Genetica, 23, 10-13.

SAKAI, K. I. AND PARK, G. Y. 1971. Genetic studies in natural populations of forest trees: genetic differentiation within a forest of Cryptomeria japonica. Theor. Appl. Genet., 41, 13-17.

SCHAAL, B. A. 1975. Population structure and local differentiation in Liatris cylindracea. Am. Nat., 109, 511-528.

SHEA, K. L. 1985. Mating system and population structure in engelmann spruce and subalpine fir. Ph.D. Thesis, University of Colorado, Boulder.

SLATKIN, M. AND ARTER, H. E. 1991. Spatial autocorrelation methods in population genetics. Am. Nat., 138, 499-517.

SOKAL, R. R. AND JACQUEZ, G. M. 1991. Testing inferences about microevolutionary processes by means of spatial autocorrelation analysis. Evolution, 45, 152-168.

SOKAL, R. R., JACQUEZ, G. M. AND WOOTEN, M. C. 1989. Spatial autocorrelation analysis of migration and selection. Genetics, 121, 845-855.

SOKAL, R. R. AND ODEN, N. L. 1978. Spatial autocorrelation in biology. 1. Methodology. Biol. J. Lin. Soc., 10, 199-228. 2. Some biological implications and four applications of evolutionary and ecological interest. Biol. J. Lin. Soc., 10, 229-249.

SOKAL, R. R. AND ODEN, N. L. 1991. Spatial autocorrelation analysis as an inferential tool in population genetics. Am. Nat., 138, 518-521.

SOKAL, R. R. AND WARTENBERG, D. E. 1983. A test of spatial au tocorrelation analysis using an isolation-by-distance model. Genetics, 105, 219-237.
THIEBAUT, B., CUGUEN, J., COMPS, B. AND MERZEAU, D. 1990. Genetic differentiation in beech (Fagus sylvatica $\mathrm{L}$.) during periods of invasion and regeneration. In: Di Castri, F., Hansen, A. J., and Debussche, M. (eds) Biological Invasions in Europe and the Mediterranean Basin, pp. 379-390. Kluwer Academic Publishers, London.

THIEBAut, B., Lumaret, R. AND Vernet, P. 1982. The bud enzymes of beech (Fagus sylvatica L.). Genetic distinction and analysis of polymorphism in several French populations. Silvae Genetica, 31, 51-60.

TIGERSTEDT, P. M. A. 1973. Studies on isozyme variation in marginal and central populations of Picea abies. Hereditas, 75, 47-60.

TIGERSTEDT, P. M. A., RUDIN, D., NIEMELA, T. AND TAMMISOLA, J. 1982. Competition and neighbouring effect in a naturally regenerating population of Scots pine. Silvae Fennica, 2, $122-129$.

VAN DAMME, J. M. A. 1986. Gynodioecy in Plantago lanceolata L. V. Frequencies and distribution of nuclear and cytoplasmic genes. Heredity, 56, 355-364.

WAGNER, D. B., SUN, Z., GOVINDARAJU, D. R. AND DANCIK, B. P. 1991. Spatial patterns of chloroplast DNA and cone morphology variation within populations of a Pinus banksianaPinus contorta sympatric region. Am. Nat., 138, 156-170.

WASER, N. M. 1987. Spatial genetic heterogeneity in a population of the montane perennial plant Delphinium nelsonii. Heredity, 58, 249-256.

WEIR, B. S. AND COCKERHAM, C. C. 1984. Estimating F-statistics for the analysis of population structure. Evolution, 38 , $1358-1370$

WRIGHT, s. 1943. Isolation by distance. Genetics, 28, 114-138.

WRIGHT, s. 1946. Isolation by distance under diverse systems of mating. Genetics, 31, 39-59.

Wright, s. 1951. The genetical structure of populations. Ann. Eugenics, 15, 323-354.

WRIGHT, s. 1965. The interpretation of population structure by F-statistics with special regard to systems of mating. Evolution, 19, 395-420.

YACINE, A. 1987. Une étude d'organisation de la diversité génétique inter- et intrapopulation chez le Chêne vert: Quercus ilex L. Thèse de 3ème cycle, Université des Sciences et Techniques du Languedoc, Montpellier.

YAZDAN1, R., LINDGREN, D. AND RUDIN, D. 1985. Gene dispersion and selfing frequency in a seed-tree stand of Pinus sylvestris L. In: Gregorius, H. R. (ed.) Population Genetics in Forestry, 60, 139-154. Springer Verlag, Berlin.

ZIEHE, M. 1983. Genotypic frequencies of the offspring generation under selection or male gamete production in partially self-fertilizing plant populations. Göttingen Research Notes in Forest Genetics, Göttingen no. 5. 